\title{
Overlaping Fungsi Baitul Mal dan Kantor Urusan Agama Sebagai Lembaga Pengelola Wakaf (Kritik Terhadap Peran Baitul Mal Sebagai Lembaga Pengelola Wakaf Di Aceh)
}

\author{
Hidayatina dan Ali Muhayatsyah \\ IAIN Lhokseumawe, Indonesia \\ hidayatinatina@ymail.com muhayatsyah@gmail.com
}

\begin{abstract}
Although Aceh Qanun Number 10 of 2007 mandated Baitul Mal as a waqf manager, there was overlapping both in regulation and implementation between the Baitul Mal, KUA and BWI. The purpose of this study is to examine the obstacles and opportunities of Baitul Mal as waqf management institution in developing waqf management in Aceh. The method used is in the form of field research with the normative juridical approach. The results of this study are: a) The obstacles of Baitul Mal as Waqf Managers are: (1) the regulation of waqf management function in Baitul mal does not yet have rules for the management of waqf property; (2) the KUA function is not optimal in managing waqf because it is still limited to administrative issues and the law has not been fully implemented; and (3t The emergence of BWI to take over management of waqf has resulted in many rules and more overlapping of management of waqf; b) Baitul Mal is very likely to manage waqf because of regulation. Even though there are other institutions such as KUA and BWI that also have regulations, autonomously, the Aceh Government still has a strategic place to manage waqf.
\end{abstract}

Keyword: Waqf, Baitul Mal, KUA, BWI

\begin{abstract}
Abstrak
Walaupun Qanun Aceh Nomor 10 Tabun 2007 mengamanatkan Baitul Mal sebagai pengelola wakaf, namun terjadi overlapping baik secara regulasi maupun pelaksanaan antara Baitul Mal, KUA dan BWI. Tujuan penelitian ini adalah: mengkaji kendala dan peluang Baitul Mal sebagai lembaga pengelola wakaf dalam pengembangan pengelolaan wakaf di Aceh. Metode yang digunakan dalam bentuk penelitian lapangan dengan pedekatan yuridis normatif. Hasil penelitian ini adalah: a) Kendala Baitul Mal sebagai pengelola wakaf adalab: (1) regulasi fungsi pengelolaan wakaf pada Baitul Mal belum memiliki aturan pelaksanaan pengurusan harta wakaf. (2) Belum optimalnya fungsi KUA dalam pengelolaan wakaf karena masib terbatas pada masalah administrasi, sementara undang-undang belum sepenubnya dilaksanakan. (3) Munculnya BWI untuk mengambil alib pengelolaan wakaf berakibat banyaknya aturan-aturan dan semakin terjadi tumpang tindih terhadap pengelolaan wakaf. b) Baitul Mal sangat berpeluang untuk mengelola wakaf karena secara regulasi, walaupun ada lembaga lain seperti KUA dan BWI juga memiliki regulasi, namun secara kewenangan otonomi Pemerintah Aceh masih memiliki tempat strategis untuk mengelola wakaf.
\end{abstract}

Kata Kunci: Wakaf, Baitul Mal, KUA, BWI

Permalink/DOI: https://doi.org/10.18326/infsl3.v13i2.329-350 


\section{Pendahuluan}

Wakaf dalam bentuk peran ekonomi memiliki arti bahwa wakaf diberikan untuk mendukung perekonomian masyarakat ekonomi lemah atau masyarakat miskin. Begitu pula dengan peranan wakaf sebagai mediasi sosial bagi umat Islam, wakaf diharapkan mampu memberikan sumbangan sosial kepada masyarakat miskin yang membutuhkan agar taraf perekonomian mereka bisa meningkat. Oleh karena itu pada tataran idealnya maka harta wakaf adalah tanggungjawab kolektif guna menjaga keabadiannya. Maka dengan demikian keberadaan lembaga wakaf sangat diperlukan sebagaimana yang telah diterapkan di negara muslim.

Daerah Aceh memiliki aset serta potensi penghimpunan aset wakaf yang sangat besar. Berdasarkan data dari Kementerian Agama, tanah wakaf di Aceh dari 23 Kabupaten/Kota tersebar sebanyak 21.862 lokasi dengan luas 183,14 juta meter persegi. Sebanyak 12.649 lokasi telah bersertifikat dan terdaftar di Badan Pertanahan Nasional, sebanyak 4.996 persil dan 1.463 persil memiliki akta ikrar wakaf/akta pengganti akta ikrar wakaf (AIW/AP AIW). Selain itu ada banyak tanah wakaf yang belum terdata atau dilakukan dengan lisan saja.

Berdasarkan data Direktorat Pemberdayaan Wakaf Kementerian Agama RI hingga Maret 2016 menjelaskan bahwa jumlah harta wakaf di Aceh berjumlah 24. 898 lokasi, sedangkan harta wakaf yang sudah bersertifikat sebanyak 13.730 persil, sementara yang belum bersertifikat berjumlah 11.168 persil, dan luas total tanah wakaf di Aceh mencapai 767.869.011,58 m2. (Badan Wakaf Indonesia: 2008)

Dalam Undang-Undang Nomor 11 tahun 2006 tentang Pemerintah Aceh sebagai dasar hukum dalam pelaksanaan syariat Islam, pengelolaan harta agama dan perwujudan kekhususan Aceh dalam semua aspek kehidupan. UUPA No.11 tahun 2006 mengukuhkan keberadaan dan kewenangan Baitul Mal, berdasarkan Pasal 191 yaitu zakat, harta wakaf dan harta agama dikelola oleh Baitul Mal Aceh dan Baitul Mal Kabupaten/Kota. Dengan dasar hukum ini Aceh dapat mengatur secara lebih seksama dan terpadu seluruh harta agama yang ada dalam masyarakat dan menggali sumber harta agama baru. (Undang-Undang Nomor 11 Tahun 2006 
tentang Pemerintah Aceh)

Pengelolaan wakaf di Aceh selama ini diatur berdasarkan UU Nomor 41 Tahun 2004 tentang Wakaf dan Qanun Aceh Nomor 10 Tahun 2007 tentang Baitul Mal. Keberadaan UU Wakaf sudah cukup komprehensif untuk mengatur tata kelola wakaf di Indonesia (Nasir: 2017). Persoalan yang muncul, sejauh mana Baitul Mal Aceh dapat menggunakan kewenangan, melakukan pembinaan dan pengawasan terhadap nadzir, serta melakukan pemberdayaan harta wakaf, sementara di sisi lain hal tersebut juga menjadi kewenangan dari Badan Wakaf Indonesia (BWI) dan Kantor Urusan Agama (KUA) di bawah Kementrian Agama yang diamanatkan dalam UndangUndang Nomor 41 Tahun 2004 Tentang Wakaf.

Sinergisitas dalam pengelolaan wakaf, seperti menyelesaikan sengketa wakaf dan memproduktifkan harta wakaf potensial antara Baitul Mal, BWI, dan KUA tetap diperlukan untuk menjamin pemberdayaan harta wakaf menjadi lebih optimal. Polemik yang muncul akan ada banyak regulasi jika ada lebih dari satu lembaga menangani satu hal, Baitul Mal Aceh dan BWI harus memiliki sinergisitas agar terdapat pengelolaan regulasi yang baik. Tentunya regulasi yang diberikan harus menjawab permasalahan mengenai overlaping pengelolaan wakaf itu sendiri, penghimpunan dana, penyaluran dana serta administrasi wakaf harus dapat dilakukan secara baik dan sederhana.

Persoalan lainnya mengenai overlaping efektifitas pengelolaan wakaf adalah pembinaan nadzir termasuk upaya melakukan monitoring dan evaluasi terhadap nadzir, memproduktifkan wakaf, pengaturan perubahan harta wakaf, pengawasan penukaran wakaf dan membuat kebijakan bidang perwakafan masih memerlukan sinergi antar lembaga untuk menyelesaikan persoalan tersebut. (Husen, 2018)

Qanun Aceh Nomor 10 Tahun 2007 menetapkan kedudukan Baitul Mal sebagai Lembaga Daerah. Dalam ketentuan Qanun tersebut, pengelolaan aset wakaf di Aceh dilaksanakan oleh Baitul Mal. Namun faktanya, dalam hal ini Baitul Mal lebih mengedepankan peran dan fungsinya terhadap pengelolaan zakat, dan pengelolaan terhadap wakaf terkesan jadi terabaikan. Ini dibuktikan dengan 
masih jauh kurang efektifnya pengelolaan wakaf yang dilakukan nadzir yang ditunjuk oleh Baitul Mal sebagai pelaksana pengelolaan wakaf.

Pemahaman nadzir terhadap pengelolaan wakaf dinilai hanya sebatas pelaksanaan pengelolaan wakaf sesuai dengan hukum Islam yang sudah mereka terapkan sejak dahulu, sehingga nadzir dalam mengelola harta wakaf tersebut sesuai dengan niat wakif dan tidak berani mengelolanya di luar yang diperuntukkan oleh wakif, akibatnya banyak tanah wakaf yang tidak bisa diproduktifkan. Kemudian belum efektifnya pembinaan terhadap pengembangan kemampuan Imam Gampong sebagai nazir wakaf dalam hal manajemen pengelolaan harta wakaf dari pihak Baitul Mal.

Namun jauh sebelum dikeluarkannya Qanun Aceh Nomor 10 Tahun 2007, KUA merupakan lembaga yang salah satu fungsinya adalah sebagai pengelola wakaf berdasarkan Undang-Undang Nomor 41 Tahun 2004 tentang wakaf, juga turut serta mengelola wakaf di Aceh. Pengelolaan dan pemberdayaan harta wakaf dilaksanakan oleh "Imam Gampong" yang bertindak sebagai nadzir wakaf dan diawasi oleh KUA di setiap Kecamatan di Kabupaten/ Kota.

Selain sebagai nadzir pengelolaan wakaf, KUA juga sebagai PPAIW (Pegawai Pencatat Akta Ikrar Wakaf) bagi wakif yang berkeinginan mewakafkan hartanya. Peran KUA sebagai PPAIW dalam penyelenggaraan pendaftaran tanah wakaf berjalan sesuai dengan peraturan perundang-undangan. Akan tetapi peran dari KUA hanya sampai pada pembuatan PPAIW dan mengurus kelengkapan administrasi saja sedangkan untuk pengajuan ke Kantor Pertanahan dilakukan secara kolektif oleh Kantor Kementerian Agama. Peran mediasi KUA dalam penyelesaian sengketa wakaf masih terbatas, sengketa yang diselesaikan lebih banyak dengan musyawarah mufakat tanpa atau tidak sampai gugatan di Pengadilan Agama (Yulianti, 2017). Kemenag telah melakukan beberapa hal, misalnya mengeluarkan Akte Ikrar Wakaf, sertifikasi wakaf, pembinaan nadzir, serta sosialisasi dan edukasi. Namun belum sebanding dengan potensi wakaf dan berbagai masalah yang dihadapi pada pengelolaan wakaf di Aceh. 
Permasalahan yang terjadi dalam pengelolaan wakaf berdasarkan paparan di atas, termasuk juga belum optimalnya pembinaan oleh Baitul Mal terhadap para nadzir tentang manajemen pengelolaan wakaf, di mana seharusnya menjadi salah satu tugas yang harus diemban oleh Baitul Mal selaku lembaga pengelola zakat, wakaf dan harta agama lainnya, sesuai dengan yang diamanahkan dalam Qanun Aceh Nomor 10 Tahun 2007. Kemudian, dengan terjadinya overlaping antara fungsi Baitul Mal dan KUA atau dualisme lembaga wakaf di Aceh, hal ini bertentangan dengan amanat pasal 15 UU Nomor 23 Tahun 2011 bahwa Baitul Mal adalah satu-satunya lembaga yang memiliki kewenangan mengelola zakat, harta wakaf dan harta agama lainnya. Terhadap persoalan tersebut tentunya juga berdampak terhadap pengembangan pengelolaan wakaf di Aceh.

\section{Metode Penelitian}

Jenis Penelitian

Penelitian ini merupakan penelitian lapangan (field research). Penelitian ini masuk penelitian kualitatif dengan bantuan data kualitatif. Layaknya penelitian kualitatif menggunakan analisis kualitatif dengan bentuk penalaran induksi analitik yang dipakai pada teori lapangan (grounded theory). Teori ini merupakan posisi sentral dalam paradigma kualitatif (Brannen, 1996)

Adapun pendekatan dalam penelitian ini adalah yuridis normatif, di mana perumusan dan penyajian atau pembahasan yang digunakan dengan tidak disajikan dalam bentuk angka-angka.

\section{Sumber Data}

Data penelitian ini diklasifikasikan menjadi dua bagian yaitu: Data primer, yaitu meliputi:

Undang-undang yang berkenaan dengan pengelolaan wakaf Undang-Undang Nomor 11 tabun 2006 tentang Pemerintahan Aceh, Qanun Aceh Nomor 7 Tahun 2010 tentang Baitul Mal.

Wawancara dengan para pibak terkait dengan pengelolaan wakaf di Provinsi Aceh. Dalam hal ini untuk lebih memudabkan penghimpunan data, dalam hal ini penulis banya mewawancarai pengelola wakaf di Baitul Mal Kota Lhokseumawe, KUA Kecamatan Banda Sakti, KUA Kecamatan Muara Dua dan Kankemenag Kota Lhokseumawe. 
Data sekunder yaitu referensi-referensi tentang pengelolaan wakaf hasil penelitian serta jurnal yang relevan dengan penelitian.

Teknik Pengolahan dan Analisis Data

Sumber data primer dan sekunder tersebut dikumpulkan dengan cara ditelaah dan dipahami secara komprehensif. Kemudian dianalisis dengan menggunakan:

Induksi dengan menarik kesimpulan dari hal yang bersifat khusus ditarik ke hal bersifat umum, yakni berfikir dari fakta yang bersifat khusus kemudian ditarik kesimpulan yang bersifat umum.

Deduksi dengan menarik kesimpulan dari hal yang bersifat umum ditarik ke hal yang bersifat khusus, cara ini dipakai untuk menganalisa data dengan berfikir dari pengetabuan yang bersifat umum, bendak menulis suatu kejadian yang bersifat khusus.

Komparasi dengan mengadakan perbandingan dari beberapa pendapat yang berbeda untuk mencari informasi yang valid atau untuk mencapai kemungkinan dalam pengkompromian.

\section{Wakaf di Indonesia}

Wakaf di Indonesia sudah ada sejak berdirinya Islam sebagai kekuatan sosial dan poltik hingga berdirinya kerajaan Islam di nusantara di abad 12 M. Tradisi wakaf dimulai sejak abad 15 M di Jawa Timur dengan dengan ditemukannya bukti-bukti historis wakaf baru ada pada awal abad ke-16 (Djatnika, 1982). Di Sumatera, Aceh, wakaf disebutkan mulai muncul abad ke-14 M (Gazalba, 1989).

Praktik wakaf terdapat dalam tradisi penyerahan tanah di beberapa daerah. Misalnya, di Mataram, telah dikenal dengan tanah perdikan, di Lombok disebut tanah pareman, tradisi masyarakat Baduy di Cibeo, Banten Selatan dikenal huma serang, di Minangkabau disebut tanah pusaka (tinggi), kemudian di Aceh dikenal tanah wnkeuh (Ali, 1988).

Jejak tumbuhnya wakaf dimulai abad $12 \mathrm{M}$ ketika penyebaran Islam oleh para sufi di nusantara, hingga abad 14 ajaran Islam semakin meluas dan mulai masuk melalui pintu kerajaan di nusantara. Misanya saja seperti Walisongo oleh Syekh Maulana Malik 
Ibrahim (w.1419M), dan Sunan Ampel (w.1467M) yang melakukan penyebaran Islam dengan mendirikan pesantren dan masjid di lingkungan kesultanan yang berguna sebagai institusi wakaf yang menjadi benih perkembangan filantropi Islam pada masa berikutnya (Djatnika, 1982).

Pada abad 14 M penyebaran Islam di Aceh juga dilakukan melaui pendirian masjid dan meunasah yang multifungsi sebagai tempat ibadah keagamaan juga sarana proses pengembangan pendidikan, aktivitas sosial, politik, kebudayaan, dan sebagainya (Nadjib dan Ridwal, 2006). Dalam struktur birokrasi kerajaan, masjid di Aceh mempunyai tugas mengelola dan mengurusi persoalanpersoalan keagamaan, seperti pernikahan, shalat, zakat, wakaf, dan lain-lain. Wakaf untuk masjid maupun kegiatan dakwah masih terjadi hingga sekarang, paraktik wakaf untuk masjid, madrasah (sekolah), dan pesantren masih tetap berjalan (Tuti dan Ridwal, 2006).

Gambaran tradisi wakaf merupakan fakta sejarah hampir merata terjadi di nusantara. Rata-rata dilakukan melalui dengan corak penyebaran Islam dari tradisi pemanfaatan wakaf (Tuti dan Ridwal, 2006). Dilakukan melalui pendirian masjid dan pesantren, juga sebagian tanah wakaf guna pengembangan sekolah-sekolah agama, seperti thawalib, parabek, dan diniyah (Azra, 2003).

Fakta lainnya juga dikemukaan Hurgronje dalam bukunya Makkah, harta wakaf dalam bentuk rumah tinggal juga pernah didirikan di luar negeri, tepatnya di Makkah oleh para Sultan di Nusantara. Kegunaannya untuk memfasilitasi para jamaah haji. Di antara rumah wakaf yang cukup terkenal adalah rumah wakaf Aceh, rumah wakaf Banten, dan rumah wakaf Pontianak (Hungronje, 1992).

Dalam perkembangannya terdapat wakaf untuk kesejahteraan sosial. Misalnya wakaf tanah dan bangunan dari Sultan Notokusumo I Raja Sumenep tahun 1786 M untuk fakir miskin. Pemberian wakaf untuk kesejahteraan sosial semacam ini didorong oleh siasat untuk mencegah tanah tersebut jatuh VOC (Djatnika, 1982).

Untuk pemanfaatan harta wakaf ke arah produktif sangat jarang dilakukan hanya sebagian kecil masyarakat yang menyerahkan 
beberapa sawahnya sebagai wakaf untuk mendanai berbagai kegiatan masjid atau madrasah. Pada saat itu fokus pemanfaatan wakaf lebih untuk langgar, masjid, pemakaman, dan pesantren karena ulama membutuhkan prasarana untuk menyebarkan dakwah dan ajaran Islam pada masyarakat. Menurut Rahmat Djatnika, dari 303 lokasi wakaf seluas $458.953 \mathrm{~m} 2$, hampir semuanya berupa tanah kering dan hanya terdpat 6 buah wakaf sawah yang luasnya mencapai $4.620 \mathrm{~m} 2$.

Dapat diduga kegiatan sosial keagamaan lebih banyak didanai oleh kegiatan filantropi Islam selain wakaf, yaitu Zakat, Infak dan sedekah (ZIS) dibandingkan dengan wakaf. Terdapat sedikit contoh kasus beberapa organisasi keagamaan seperti pesantren yang dapat bertahan hidup dengan memanfaatkan hasil wakaf yang dikelolanya secara produktif, yaitu Pesantren Tebuireng Jombang dan Pondok Modern Gontor (Djatnika, 1982).

Wakaf pada masa pemerintahan Hindia Belanda mendapat perhatian ditandai dengan adanya peraturan yang berkenaan dengan wakaf. Pada waktu Pengadilan Agama (Priesterraad) didirikan berdasarkan Staatsblad No.152 Tahun 1882, salah satu kewenangnya adalah menyelesaikan masalah wakaf. Peraturan lalinnya seperti surat Edaran Sekretaris Gubernemen tanggal 4 Juni 1931 No.125/3 (Hasanah, 2009).

Selanjutnya pemerintah Kolonial Belanda mengeluarkan aturan, yaitu Edaran Gubernemen tanggal 24 Desember 1934 No.3088/A termuat dalam Bjiblad tahun 1934 No. 13390. Dengan beberapa penegasan tentang prosedur perwakafan, bahwa setiap perwakafan harus diberitahukan kepada bupati, dengan tujuan supaya bupati dapat mempertimbangkan atau meneliti peraturan umum atau peraturan setempat. Surat Edaran ini sifatnya untuk mempertegas terhadap Surat Edaran Sekretaris Gubernemen tanggal 27 Mei 1935 No.1273/A seperti yang termuat dalam Bjiblad 1935 No.13480. Dalam Surat Edaran ini Bagi yang dilanggar agar bupati dapat mendaftarkan wakaf itu dalam daftar yang disediakan untuk itu (Hasanah, 2009).

Selanjutnya pemerintah melalui Departemen Agama dalam mengurus wakaf mengeluarkan Peraturan Pemerintah No.33 tahun 
1949 jo., Peraturan Pemerintah No. 8 Tahun 1980, serta Peraturan Menteri Agama No.9 dan No.10 Tahun 1952. Dalam peraturan tersebut kewenangan perwakafan tanah oleh Menteri Agama dalam pelaksanaannya dilimpahkan kepada KUA untuk mengawasi, meneliti, dan mencatat perwakafan tanah agar sesuai dengan maksud dan tujuan perwakafan dalam agama Islam. Sedangkan perwakafan yang telah ada sebelum berlakunya peraturan tersebut, dapat dibuatkan surat bukti baru berdasarkan kesaksian yang ada.

Langkah penertiban wakaf, kantor Pusat Jawatan Agama mengeluarkan Surat Edaran No.5. tanggal 31 Desember 1956 yang menganjurkan agar perwakafan tanah dibuat dengan cara tertulis. Sehubungan dengan adanya surat Keputusan bersama antara menteri Dalam Negeri dan Menteri Argraria tertanggal 5 Maret 1959 No.Pem. 19/22/23/7;SK/62/Ka/59P, pengesahan perwakafan tanah milik yang semula menjadi wewenang bupati dialihkan kepada Kepala Pengawas Agraria. Pelaksanaan selanjutnya diatur dengan Surat Pusat Jawatan Agraria kepada Pusat Jawatan Agraria tanggal 13 februari 1960 No.Pda.2351/34/II (Hasanah, 2009).

Dari peraturan yang telah dikemukakan di atas, Departemen Agama pada tanggal 22 Desember 1953 mengeluarkan petunjuk mengenai wakaf. Seperti adanya jawatan urusan Agama pada Surat Edaran Jawatan Urusan Agama tanggal 8 Oktober 1956, No. 3/D/1956 tentang wakaf yang bukan milik keMasjidan.

Peraturan pemerintah pada waktu itu dinilai belum memadai karena banyak tanah wakaf yang masih terbengkalai, bahkan ada yang hilang. Dalam rangka pembaruan hukum agraria, persoalan tentang perwakafan tanah diberi perhatian khusus dalam Undangundang pokok Agraria, yaitu UU No. 5 Tahun 1960 Tentang Peraturan Dasar Pokok-Pokok Agraria, Bab II, Bagian XI, pasal 49. Dalam Pasal 49 ayat (3) disebutkan bahwa "untuk melindungi dan berlangsungnya perwakafan tanah di Indonesia, pemerintah akan memberikan pengaturan melalui PP tentang Perwakafan Tanah Milik". PP tersebut ternyata baru dikeluarkan setelah 17 tahun berlakunya UU Pokok Agraria. Dengan adanya peraturan tentang perwakafan tanah milik, diharapkan tanah wakaf lebih tertib dan terjaga. 
Dalam perjalanannya, sejarah wakaf terus mengalami perkembangan seiring dengan laju perubahan zaman dengan berbagai inovasi yang relevan, seperti bentuk wakaf uang, wakaf hak atas Kekayaan Intelektual (HAKI), dan lain-lain. Di Indonesia sendiri, saat ini wakaf kian mendapat perhatian yang cukup serius dengan diterbitkannya Undang-Undang No. 41 tahun 2004 tentang Wakaf dan PP No. 42 tahun 2006 tentang pelaksanaannya (Sutaarmadi dan Amidhan, 1990).

\section{Peraturan Perundang-Undangan Wakaf di Indonesia}

Peraturan terkait perwakafan di Indonesia diantaranya adalah: Undang-Undang Pokok Agraria, (Presiden RI: 1960)

Dalam UU Pokok Agraria disebutkan beberapa pasalnya menjelaskan tentang keberadaan tanah-tanah yang ada untuk tempat peribadatan yang sebelumnya belum terkafer secara menyeluruh dalam hukum adat. Untuk itu maka dikeluarkanlah UU Pokok Agraria yang menetapkan tanah-tanah yang ada pada masa itu sebagai tempat peribadatan. Hal ini sesuai dengan pengaturan yang terkandung di dalam beberapa pasal di antaranya: (Departemen Agama RI, 2007)

Pasal 5 UUPA menyebutkan "bahwa bumi, air dan kekayaan alam yang ada dan ruang angkasa yang ada di bumi adalah sesuai dengan bukum adat, sepanjang tidak bertentangan dengan kepentingan nasional dan negara segala sesuatu dengan mengindabkan unsur-unsur yang bersandar pada bukum agama”. Pasal ini dijelaskan bukum adat menjadi dasar bukum agraria di Indonesia, bukum yang tidak tertulis dalam bentuk UU yang mengandung unsur agama yang telah diresipir dalam lembaga bukum adat, khususnya lembaga wakaf.

Pasal49UUPA menyatakan "bahwahakmiliktanaholeh badan keagamaan dan sosial dipergunakan untuk usaha bidang keagamaan, dan sosial serta diakui dan dilindungi negara". Dalam pasal ini diatur tentang perwakafan, bahwa soal-soal yang bersangkutan dengan peribadatan dan keperluan suci lainnya dalam bukum agraria akan mendapatkan perhatian sebagaimana mestinya. Terkait dengan hal itu pemerintah Republik Indonesia telah mengeluarkan peraturan tentang 
perwakafan tanah hak milik, yaitu PP No.28 Tahun 1977 (Presiden RI: 1977).

Inpres Nomor 1 Tahun 1991 Tentang Kompilasi Hukum Islam (KHI)

Instruksi Presiden Republik Indonesia Nomor 1 Tahun 1991 berisi tentang perintah kepada Menteri Agama RI dalam menyebarluaskan Kompilasi Hukum Islam (KHI). Penjelasan tentang masalah perwakafan menurut KHI untuk pengembangan dan penyempurnaan pengaturan perwakafan sesuai hukum Islam. Hukum perundang-undangan ini merupakan kelanjutan dari peraturan yang ada dalam UUPA, karena dalam UUPA memiliki objek yang terbatas pada benda tak bergerak dan tujuannya lebih banyak untuk tujuan tempat peribadatan.

Undang-Undang Nomor 41 Tabun 2004 Tentang Wakaf (Presiden RI: 2004)

Dalam Undang-undang ini dijelaskan beberapa substansi berkenaan dengan wakaf dan pengelolaannya lebih diarahkan kepada pengelolaan produktif. Pada masa UUPA dan KHI diberlakukan peruntukan wakaf dominan mengarah kepada kepentingan tidak produktif seperti Masjid, Mushalla, Madrasah, kuburan Yayasan, Pesantren/Sekolah dan sebagainya sehingga wakaf kurang optimal. Dengan melihat hal demikian, menarik perhatian Presiden RI SBY untuk menandatangani UU wakaf terbaru ini pada tanggal 2 Oktober 2004. Dengan berlakunya UU ini keberadaan wakaf lebih luas lagi baik objek, pengelolaan serta peruntukannya, dan hubungan wakaf dengan peningkatan perekonomian umat Islam.

Peraturan Pemerintah Nomor 42 Tabun 2006

Peraturan Pemerintah Nomor 42 Tahun 2006 tentang Pelaksanaan Undang-undang No.41 Tahun 2004 tentang Wakaf yang terdiri atas 11 bab, 61 pasal. Hal ini dikeluarkan karena perturan UU terbaru wakaf belum dilaksanakan dan untuk menjalankannya keluarlah PP No.42 Tahun 2006. Dalam PP tersebut dimuat ketentuan umum, nadzir, jenis harta benda wakaf, akta ikrar wakaf dan pejabat pembuat akta ikrar wakaf, tata cara pendaftaran dan pengumuman harta wakaf, bantuan pembiayaan Badan Wakaf Indonesia, pembinaan dan pengawasan, sanksi administratif, ketentuan peralihan dan penutup. 


\section{Pengelolaan Wakaf di Aceh}

Sejarah Pengelolaan Wakaf di Aceh

Kerajaan Aceh Darussalam berdiri sejak tahun $916 \mathrm{H}$ telah mempunyai undang-undang yang bernama "KANUN MEUKUTA $A L A M "$ atau kanun Al-asyi. Di antara lembaga pemerintah yang termaktup dalam kanun MEUKUTA ALAM tersebut, terdapat sebuah lembaga yang bernama Balai Meusara Balai ini bertugas mengelola semua bidang perwakafan. Meusera wakaf pada waktu telah dikelola dengan sistem yang integral, sehingga lembaga-lembaga agama dan sosial seperti dayah, mesjid, madrasah, mempunyai meusara yang banyak, untuk membiayai kebutuhan lembaga itu. Bahkan balai pendidikan tinggi di kerajaan Aceh Darussalam yang berpusat di ibu kota Kerajaan Aceh Darussalam, sering disebut dengan istilah "al-azhar shaghir" karena memiliki meusara yang amat banyak.

Sesuai dengan data yang diperoleh, di Aceh tanah wakaf sebanyak 21.862 lokasi dengan luas 183,14 juta meter persegi. Sementara di Aceh Utara ada 3251 persil (lokasi) yang sudah bersertifikat sekitar 1200 persil (sekitar 30\%) Dari jumlah itu yang telah bersertifikat 12.649 lokasi selebihnya belum bersertifikat Asset wakaf di aceh kebanyakan berupa tanah, seperti kebun, sawah, tambak, tanah kuburan, mesjid, meunasah, pesantren, panti asuhan dan madrasah.

Bila dipersentasikan hanya sekitar 20\% yang diatasnya telah didirikan bangunan seperti tersebut diatas, sedangkan $75 \%$ lagi belum dapat dimanfaatkan baik secara sosial maupun secara ekonomis, sistem ini sudah bertahan puluhan tahun dari generasi ke generasi bahkan sudah berabad, ini terjadi karena berbagai sebab, antara lain sebagai berikut (Idris: 4):

Selama ini pandangan masyarakat tertekan tentang pentingnya pelestarian dan keabadian tanah wakaf, sebingga harta wakaf tidak boleh sedikitpun di utak-atik peruntukan manfaatnya di luar pernyataan si wakif.

Pengangkatan Nadzir (pengelola harta wakaf) pada umumnya belum mengikuti prosedur atau peraturan yang berlaku, sebingga betapa banyak harta wakaf di aceh yang dikelola oleh Nadzir perorangan yang silib berganti secara turun temurun, 
akibatnya, banyak harta wakaf yang sudab berpindah tangan dan tidak tabu nasibnya.

Penambahan harta wakaf akan sangat lamban di Aceh, dalam satu tabun mungkin tidak ada penambahan barang 100 persil, hal ini disebabkan oleb beberapa hal (Idris: 5):

Tingkat kesadaran umat tentang berwakaf semakin menurun, karena penerangan tentang keunggulan barta yang diwakafkan semakin tidak bergema baik melalui ceramah, khutbah, maupun melalui pengajian sehingga masyarakat sudah tabu dengan persoalan wakaf.

Karena terbatasnya lahan yang tersedia, saat ini sangat susab untuk diwakafkan sepetak tanah, sementara untuk membangun rumah saja tidak tersedia laban. Hal ini sangat berbeda dengan orang yang bidup $30 \mathrm{~s} / \mathrm{d} 50$ tabun yang lalu dimana waktu itu lahan kebun sawah masib banyak karena penduduknya masih sedikit.

Adanya pemahaman yang agak ketat dalam masyarakat babwa harta wakaf (mauquf bih) harus benda yang tetap tidak bergerak seperti kebun, sawah, ladang, tambak dan lain-lain yang tidak bergerak, sedangkan mewakafkan benda yang bergerak dan tidak tetap, seperti mewakafkan logam mulia, uang, surat berharga, sabam, kekayaan intelektual saat ini dalam pandangan sebahagian besar masyarakat aceh akan semakin sulit.

Landasan Yuridis Pengelolaan Wakaf di Aceh

Pembentukan lembaga formal pengelola zakat di Aceh dilakukan tahun 1973 melalui Keputusan Gubernur Kepala Daerah Istimewa Aceh No.5/1973 tentang Pembentukan Badan Penertiban Harta Agama (BPHA). Pada tahun 1975 BPHA ini kemudian dirubah menjadi Badan Harta Agama (BHA). Pada tahun 1998 BHA berubah menjadi BAZIS di Aceh, karena adanya Keputusan Bersama Menteri Agama dan Menteri Dalam Negeri tahun 1991 tentang Pembentukan BAZIS (Badan Amil Zakat, Infak dan Shadaqah). BAZIS di Aceh terdiri dari Provinsi, Kabupaten/Kota, Kecamatan dan Gampong/ Kelurahan. BAZIS berubah menjadi Badan Baitul Mal Aceh melalui 
Keputusan Gubernur No.18/2003 tentang Pembentukan Organisasi dan Tata Kerja Badan Baitul Aceh yang beroperasi pada bulan Januari 2004.

Pada tahun 2008 disahkannya Qanun Aceh Nomor 10 Tahun 2007 tanggal 17 Januari 2008 tentang Baitul Mal. Undang-Undang Nomor 11 Tahun 2006 tentang Pemerintah Aceh, lebih mempertegas nuansa otonomi yang bersifat khusus. Hal ini terkait adanya adanya implementasi formal terhadap penegakan syari'at Islam. Salah satu ketentuan yang diamanahkan Undang-Undang tersebut dan merupakan salah satu bagian dari anatomi keistimewaan Aceh adalah pembentukan Baitul Mal sebagai lembaga formal pengelola zakat, harta wakaf dan harta agama (Baitul Mal Aceh).

Adapun sasaran yang ingin dicapai oleh Baitul Mal yaitu: Qanun tentang Baitul Mal merupakan wadah untuk menampung implementasi dari ketentuan yang diatur dalam pasal 180 ayat (1) huruf d, pasal 191 dan pasal 192 Undang-Undang Nomor 11 Tahun 2006 tentang Pemerintahan Aceh.

Baitul Mal merupakan sebuah lembaga formal yang dapat mengoptimalkan pendayagunaan zakat, harta wakaf, dan harta agama sebagai potensi umat Islam yang cukup besar yang selama ini kurang diperhatikan.

Terciptanya distribusi kewenangan dan derajat pertanggung jawaban untuk masing-masing tingkat Baitul Mal (Provinsi, Kabupaten/Kota dan Gampong).

Adanya kesamaan gerak dalam pengelolaan zakat, harta wakaf dan harta agama sebagai eksistensi otonomi khusus dalam membangun kebersamaan, sinkronisasi dan harmonisasi dari Baitul Mal Aceh, Baitul Mal Kabupaten/Kota dan Baitul Mal Gampong (Ashari, 2006).

\section{Kendala dan Peluang Baitul Mal Terhadap Pengembangan Pengelolaan Wakaf di Aceh}

Kendala Baitul Mal Kota Lhokseumawe Sebagai Pengelola Wakaf

Baitul Mal dan KUA keduanya memiliki kewenangan dalam mengelola harta wakaf. Selama ini antara kedua lembaga tersebut masih belum bersinergi dalam pengelolaan wakaf sehingga mengalami kendala dalam pengembangan wakaf di Lhokseumawe. 
Beroperasinya lembaga pengelola wakaf tersebut sebenarnya diharapkan mampu menjadi sarana untuk memperkuat fungsi wakaf dalam membantu dan memberdayakan perekonomian masyarakat.

Namun demikian, karena regulasi yang tidak jelas khususnya di Aceh, terhadap pengelolaan wakaf antara Baitul Mal dan KUA, menyebabkan terjadinya overlapping pengelolaan wakaf antara Baitul Mal dan KUA. Sementara Undang-Undang Pemerintah Aceh telah mengamanahkan pengelolaan wakaf tersebut kepada Baitul Mal, dan ini berakibat terhadap kurang terurusnya pengelolaan wakaf dari kedua lembaga pengelola wakaf tersebut.

Baitul Mal Lhokseumawe mengalami beberapa kendala, diantaranya belum adanya aturan pelaksanaan oleh Pemerintah Kota Lhokseumawe mengenai aturan pelaksanaan tata kelola perwakafan, hal ini menyulitkan Baitul Mal dalam melaksanakan fungsinya dalam memberikan pelayanan bidang wakaf. Akan tetapi pihak Baitul Mal berpendapat jika ada harta wakaf yang masuk ke Baitul Mal, maka wajib bagi Baitul Mal mengurusnya karena itu merupakan harta agama. Secara struktur organisasi di Baitul Mal memiliki bidang yang mengurus masalah wakaf. Pelayanan wakaf untuk saat ini lebih terarahkan kepada KUA dengan fungsi melakukan pengadministrasian harta wakaf (Boihaki: 2018).

Berdasarkan hasil wawancara yang penulis lakukan dengan dengan kepala Baitul Mal kota Lhokseumawe, dijelaskan bahwa yang menjadi kendala mengelola dan mengembangkan wakaf khususnya di Lhokseumawe adalah mengenai pemanfaatan harta wakaf yang mayoritas masyarakat masih menganggap harta wakaf tidak bisa diubah atau mengalihkan wakaf ke bentuk lainnya, hanya diperuntukkan untuk masjid dan kuburan, bahkan dibeberapa tempat tanah-tanah wakaf tersebut tidak termanfaatkan dan sering terabaikan. Kesulitan ini berakibat banyak tanah wakaf yang menganggur (Boihaki: 2018).

Kendala yang dihadapi oleh Baitul Mal juga diperkuat lagi munculnya kendala tersebut dari KUA. Selama ini fungsi KUA lebih menjalankan aspek adminitrasi perwakafan sebagai PPAIW. Sementara aspek lainnya menjadi sering terabaikan, misalnya penunjukan seorang nazhir wakaf masih diserahkan melalui tokoh 
agama (imumgampong) desa setempat. Menurut peraturan undangundang tentang wakaf seorang nazhir seharusnya wajib didaftarkan pada menteri dan BWI melalui Kantor Urusan Agama setempat, kemudian BWI menerbitkan tanda bukti pendaftaran nazhir.

Dalam praktiknya penunjukkan nazhir wakaf masyarakat (wakif) sering tidak mempertimbangkan kemampuan nazhir selaku pengurus wakaf baik dalam peraturan perundang-undangan maupun hukum Islam berkaitan wakaf. Pemahaman selama ini masih melaksanakan tugas dan tanggung jawab sesuai amanah yang disampakan oleh wakif dan sesuai perintah dari aparatur desa dan KUA Kecamatan (Hasyim: 2018).

Kendala Baitul Mal sebagai pengelola wakaf terletak pada koordinasi antara Baitul Mal mengenai regulasi, ditambah lagi kendala dengan terbentuknya kepengurusan BWI di Aceh. Akan menjadi sebuah polemik tersendiri, karena kedua lembaga tersebut memiliki masing-masing regulasi sebagai dasar pengelolaan wakaf. Hal ini akan menimbulkan adanya banyak regulasi dan tumpang tindih antara satu lembaga dengan lembaga lainnya jika ada lebih dari satu lembaga menangani harta wakaf.

Selama ini BWI telah banyak melahirkan regulasi tentang pengelolaan perwakafan, kumpulan regulasi yang telah ada diantaranya adalah:

Peraturan BWI No.1 Tabun 2007 tentang Organisasi dan Tata Kerja Badan Wakaf Indonesia;

Peraturan BWI No.1 Tahun 2008 tentang Prosedur Penyusunan Rekomendasi Terhadap Permohonan Penukaran/Perubahan Status Harta Benda Wakaf;

Peraturan BWI No.2 Tabun 2008 tentang Perwakilan Badan Wakaf Indonesia;

Peraturan BWI No.3 Tahun 2008 tentang Tata Cara Pendaftaran dan Penggantian Nazhir Harta Benda Wakaf Tidak Bergerak Berupa Tanah;

Peraturan BWI No.1 Tabun 2009 tentang Pedoman Pengelolaan dan Pengembangan Harta Benda Wakaf Bergerak Berupa Uang; Peraturan BWI No.2 Tahun 2009 tentang Pedoman Penerimaan 
Wakaf Uang Bagi Nazhir Badan Wakan Indonesia;

Peraturan BWINo.1 Tabun 2010 tentang Tata Cara Pengangkatan dan Pemberhentian Anggota Badan Wakaf Indonesia;

Peraturan BWI No.2 Tahun 2010 tentang Tata Cara Pendaftaran Nazhir Wakaf Uang;

Peraturan BWI No.3 Tahun 2010 tentang Perubahan Atas Peraturan Badan Wakaf Indonesia Nomor 2 Tabun 2008 tentang Perwakilan Badan Wakaf Indonesia;

Peraturan BWI No.4 Tabun 2010 tentang Pedoman Pengelolaan Harta Benda Wakaf;

Peraturan BWI No.2 Tabun 2012 tentang Perwakilan Badan Wakaf Indonesia.

Regulasi BWI di atas belum tertuang secara baik dalam pengelolaan wakaf oleh Baitul Mal, artinya belum berbentuk sinergisitas antar lembaga pengelola wakaf. Banyaknya lembaga dalam mengurus harta wakaf seyogyanya dapat menjadikan pengelolaan wakaf menjadi lebih baik, dan munculnya beberapa regulasi diharapkan tidak menjadikan pengelolaan harta wakaf menjadi berjalan ditempat, maka dari pada itu peran masingmasing lembaga perlu diperjelas kewenangan terhadap alur proses pengelolaan wakaf.

\section{Peluang Baitul Mal Lhokseumawe sebagai Lembaga Pengelola} Wakaf

Dari sekian kendala yang peneliti temukan di lapangan dalam pengembangan harta wakaf oleh Baitul Mal Lhokseumawe. Masih terdapat harapan yang cerah mengenai pengelolaan wakaf. Secara regulasi walaupun ada lembaga lain seperti KUA dan BWI sebagai pengelola harta wakaf yang telah memiliki regulasi. Baitul Mal secara kewenangan otonomi Pemerintah Aceh masih memiliki tempat yang strategis untuk mengelola harta wakaf. Penguatan regulasi menjadi penting dilakukan Pemerintah Aceh secara kedaerahan terutama Pemerintah Kota Lhokseumawe dengan mengeluarkan regulasi mengenai aturan pelaksanaan wakaf agar pengelolaan wakaf lebih baik. Upaya yang dilakukan adalah mensinergikan antar lembaga pengelola wakaf di Aceh dengan memperjelas kedudukan kewenangan masing-masing lembaga pengelola wakaf 
dalam undang-undang agar tidak menjadi tumpang tindih dalam proses pengelolaan harta wakaf.

Keberadaan Baitul Mal yang selama ini sudah familiar dikalangan masyarakat sebagai pengelola ZISWAF dan harta agama bagi Pegawai Negeri Sipil (PNS) menjadi nilai tambah bagi Baitul Mal dalam melakukan sosialisasi maupun penghimpunan harta agama dikalangan masyarakat. Lokasi strategis keberadaan Baitul Mal di Aceh sudah menyebar di setiap Kabupaten/Kota (Boihaki: 2018).

\section{Analisis}

Berdasarkan paparan di atas dapat dipahami bahwa regulasi fungsi Baitul Mal dan KUA sebagai lembaga pengelolaan wakaf dapat dikatakan belum berjalan optimal. Kedua lembaga tersebut walaupun telah memliki dasar dalam kewenangan pengurusan harta wakaf masih terdapat beberpa kendala dalam pelaksanaannya.

Regulasi Baitul Mal mengacu pada Qanun Aceh Nomor 10 Tahun 2007 tentang Baitul Mal dan Undang-Undang Nomor 41 Tahun 2004 tentang Wakaf. Dalam pelaksanaan teknis dilapangan Baitul Mal Lhokseumawe terdapat sejumlah kendala yang membuat pengembangan harta wakaf menjadi kurang berkembang. Pertama, adalah regulasi fungsi pengelolaan wakaf pada Baitul Mal Lhokseumawe masih belum memiliki Peraturan Pemerintah mengenai aturan pelaksanaan pengurusan harta wakaf di Baitul Mal Lhokseumawe. Kedua, belum optimalnya fungsi KUA dalam pengelolaan wakaf sesuai yang diamanatkan dalam undang-undang wakaf sehingga fungsi KUA masih terbatas pada masalah adminitrasi, sementara untuk menjalankan undang-undang belum sepenuhnya dilakukan. Ketiga, dengan munculnya BWI untuk mengambil alih pengelolaan wakaf sehingga mengakibatkan banyaknya aturanaturan dan terjadinya tumpang tindih pengelolaan wakaf.

Undang-Undang Nomor 41 Tahun 2004 dan Peraturan Pemerintah Nomor 42 Tahun 2006 tentang Pelaksanaan UndangUndang Nomor 41 Tahun 2004 tentang Wakaf, bertujuan untuk menguatkan kedudukan harta wakaf yang ada di masyarakat. Undang-undang ini lebih mengarahkan kepada pemberdayaan wakaf dalam membangun perekonomian masyarakat. Secara regulasi undang-undang tersebut ini lebih luas cakupannya karena 
didalamnya terkandung hal-hal baru yang mengatur tentang perwakafan, misalnya tentang benda wakaf bergerak, pentingnya pendaftaran benda-benda wakaf, pentingnya persyaratan pada nazhir wakaf, adanya ketentuan pidana dan sanksi administrasi serta pentingnya pembentukkan pembentukkan sebuah lembaga wakaf (BWI). Hal tersebut merupakan sebuah kemajuan dalam aturan pengelolaan wakaf.

Perbaikan yang perlu dilakukan secara cepat adalah Pemerintah Kota Lhokseumawe membuat aturan mengenai pelaksanaan pengelolaan wakaf di Baitul Mal Lhokseumawe. Pemerintah Aceh melakukan perubahan Undang-Undang Baitul Mal agar peranan Baitul Mal dalam pengelolaan wakaf bisa lebih produktif.

Upaya lainnya yang perlu dilakukan adalah mensinergikan antar lembaga pengelola wakaf di Aceh agar tidak menjadi tumpang tindih dalam pengelolaan harta wakaf. Upaya ini dilakukan dengan cara memperjelas status wewenang tugas antar lembaga baik dari segi perundang-undangan wakaf maupun Undang-Undang Baitul Mal sehingga membuat gerakan wakaf di Aceh dapat berjalan maksimal.

Hal penting lainnya dalam upaya pengelolaan wakaf dapat berkembang adalah perlu adanya perubahan konsepsi terhadap harta wakaf, dengan cara melakukan sosialisasi maupun dakwah kajian bentuk wakaf produktif secara mendalam kepada masyarakat bahwa harta wakaf bisa saja digunakan untuk tujuan produktif.

Pembenahan lain yang perlu dilakukan adalah pembenahan pada nazhir pada peningkatan pengetahuan kajian hukum Islam supaya terbuka terhadap penafsiran baru, dinamis dan potensi yang cukup besar untuk dikembangkan sesuai dengan kebutuhan zaman. Kemudian meningkatkan keahlian nazhir dalam mengelola wakaf sehingga memilikitanggung jawab terhadap harta wakaf yang dikelola. Nazhir mempunyai tugas penting yaitu, mengadministrasikan harta wakaf; mengelola dan mengembangkan harta wakaf sesuai dengan tujuan, fungsi, dan peruntukkannya; melindungi dan mengawasi harta wakaf; serta melaporkan pelaksanaan tugas kepada badan wakaf Indonesia. (Undang-Undang Nomor 41 Tahun 2004) 


\section{Kesimpulan}

Regulasi fungsi Baitul Mal dan Kantor Urusan Agama (KUA) sebagai lembaga pengelolaan wakaf dapat dikatakan belum berjalan optimal. Walaupun kedua lembaga tersebut telah memliki dasar dalam kewenangan pengurusan harta wakaf, tetapi masih terdapat beberapa kendala dalam pelaksanaannya, baik dari segi belum adanya regulasi pelaksanaan pengelolaan wakaf oleh Baitul Mal Lhokseumawe, maupun kewenangan KUA sebagai Pejabat Pembuat Akta Ikrar Wakaf (PPAIW) belum optimalnya fungsi KUA dalam pengelolaan wakaf sesuai yang diamanatkan dalam undang-undang wakaf sehingga fungsi KUA masih terbatas pada masalah adminitrasi, sementara untuk menjalankan undang-undang belum sepenuhnya dilakukan.

Undang-Undang tentang Wakaf mengarahkan kepada pemberdayaan wakaf perekonomian masyarakat. Secara regulasi cakupannya lebih luas karena didalamnya terkandung hal-hal baru yang mengatur tentang perwakafan. Pola pikir nazhir sebagai penanggungjawab atau pelopor gerakan pemberdayaan wakaf masih mengalami stagnasi pemikiran, ketidakmahiran dan ketidakmampuan dalam mendayagunakan atau pengembangan harta wakaf. Di satu sisi masih banyak nazhir yang belum menjalankan tugasnya sesuai dengan perundang-undangan wakaf. Nazhirmasih melaksanakan tugas dan tanggung jawab sesuai amanah yang disampakan oleh wakif dan sesuai perintah dari aparatur desa dan KUA. 


\section{Daftar Pustaka}

Ali, Mohammad Daud. 1988. Sistem Ekonomi Islam, Zakat dan Wakaf. Jakarta: UI Press

Ashari, Abdul Ghafur. 2006. Hukum dan Pemberdayaan Zakat. Yogyakarta: Pilar Media

Azra, Azyumardi. 2003. Surau: Pendidikan Islam Tradisional dalam Transisi dan Modernisasi. Jakarta: Logos

Badan Wakaf Indonesia. Data Tanah Wakaf Seluruh Indonesia. https://bwi. or. id/index. php/in/tentang-wakaf/data-wakaf/ data-wakaf-tanah. html. Diakses tanggal 26 November 2019

Baitul Mal Aceh. 2019. http://baitulmal. acehprov. go. id/. Diakses tanggal 26 November 2019

Boihaki. 2018. Wawancara tentang Overlaping Fungsi Baitul Mal dan Kantor Urusan Agama sebagai Lembaga Pengelola Wakaf. Wawancara Lhokseumawe: Baitul Mal

Brannen, Julia. 1996. Memadu Penelitian Kualitatif dan Kuantitatif. Yogyakarta: Pustaka Setia

Departemen Agama RI. 2007. Panduan Pemberdayaan Tanah Wakaf Produktif Strategis di Indonesia. Jakarta : Direktorat Pemberdayaan Wakaf Direktorat Jenderal Bimbingan Masyarakat Islam

Djatnika, Rahmat. 1982. Wakaf Tanah. Surabaya: Al-Ikhlas

Gazalba, Sidi. 1989. Masjid Pusat Ibadah dan Kebudayaan. Jakarta: Pustaka Al-Husna

Hasanah, Uswatun. 2009. Wakaf Produktif untuk Kesejahteraan dalam Perspektif Hukum Islam di Indonesia. Pidato Pengukuhan Guru Besar Universitas Indonesia

Hasyim, Muhammad. 2018. Wawancara tentang Overlaping Fungsi Baitul Mal dan Kantor Urusan Agama sebagai Lembaga Pengelola Wakaf. Lhokseumawe: Baitul Mal

Hungronje, Snouck. 1992. Nasihat-nasihat C. Hungronje Semasa Kepegawaiannya kepada Pemerintah Hindia Belanda 1889- 
1936. Jakarta: INIS

Husen, Sayed Muhammad. 2018. "Sinergisitas BWI dan Baitul Mal dalam Mengelola Wakaf," http://baitulmal. acehprov. go. $\mathrm{id} /$ ?p=2981. Diakses tanggal 26 November 2019

Idris, Zulkifli, Peran dan Fungsi Nadzir dalam Pemberdayaan Harta Wakaf, Dipaparkan Pada Acara Seminar Pertemuan Sekdes Aceh Utara

Nadjib, A Tuti dan Ridwal Al-Makassary. 2006. Wakaf, Tuhan dan Agenda Kemanusiaan. Jakarta: CSRS UIN

Nasir, Fahmi M. 2017. Revitalisasi Tata Kelola Wakaf Aceh. http:// aceh. tribunnews. com/2017/09/08/revitalisasi-tata-kelolawakaf-aceh. Diakses tanggal 26 November 2019

Peraturan Pemerintah Nomor 28 Tahun 1977, Jakarta: Lembaran Negara, 1977

Qanun Aceh Nomor 10 Tahun 2007 tentang Baitul Mal

Sutaarmadi, Muhda Hadisaputra dan Amidhan. 1990. Pedoman Praktis Perwakafan. Jakarta: Badan Kesejahteraan Masjid

Undang-Undang Nomor 5 Tahun 1960 tentang Peraturan Dasar Pokok Agraria. Jakarta : Lembaran Negara, 1960

Undang-Undang Nomor 11 Tahun 2006 Tentang Pemerintah Aceh.

Undang-Undang Nomor 41 Tahun 2004 tentang Wakaf

Undang-Undang Republik Indonesia Nomor 41 Tahun 2004,Jakarta : Menteri Hukum dan Hak Asasi Manusia RI, 2004

Yulianti, Wahyu. 2017. Peranan Kantor Urusan Agama (KUA) Dalam Melakukan Penyelenggaraan Pendaftaran Tanah Wakaf (Studi Pada Kantor Urusan Agama (KUA) Kecamatan Samarinda Ulu Kota Samarinda). Universitas Diponegoro: Tesis yang Dipublikasikan 